\section{Occupational exposure and effects on the male reproductive system}

\author{
Exposição ocupacional e efeitos sobre \\ o sistema reprodutor masculino
}

\author{
1 Escola Nacional de Saúde \\ Pública Sergio Arouca, \\ Fundação Oswaldo Cruz, \\ Rio de Janeiro, Brasil. \\ Correspondence \\ W. Waissmann \\ Centro de Estudos da Saúde \\ do Trabalhador e Ecologia \\ Humana, Escola Nacional de \\ Saúde Pública Sergio Arouca, \\ Fundação Oswaldo Cruz. \\ Rua Leopoldo Bulhões 1480, \\ Rio de Janeiro, $R J$ \\ 21041-210, Brasil. \\ waissman@ensp.fiocruz.br
}

\section{Abstract}

A significant increase in the incidence of male infertility has been described in the international literature, raising questions about its causes. Part of this effect may result from synthetic toxic substances acting on the endocrine system (endocrine disruptors), many of which are routinely used in work processes. We provide a critical review of the specialized literature on work-related chemical substances capable of causing male infertility. Pesticides such as DDT, linuron, and others, heavy metals like mercury, lead, cadmium, and copper, and substances from various industrial uses and residues such as dioxins, polychlorinated biphenyls (PCBs), ethylene dibromide (EDB), phthalates, polyvinyl chloride $(P V C)$, and ethanol are among the main endocrine disruptors that can cause male infertility. Based on the literature, gonadal dysfunction and congenital malformation are the main alterations caused by these substances in the male reproductive system. We conclude that despite the relative lack of studies on this issue, the relevance of such risk calls for further studies as well as measures to prevent workers' exposure to the various substances.

Male Infertility; Occupational Exposure; Endocrine System
Erika Kaltenecker Retto de Queiroz ${ }^{1}$ William Waissmann 1

\section{Introduction}

Some chemical substances have the capacity to interfere in the functioning of the endocrine system, in the hormones' mechanism of action, and are called endocrine deregulators or endocrine disruptors $1,2,3$, with the latter term adopted in this paper.

Alterations caused by endocrine disruptors can be temporary or permanent 2,4,5. Endocrine disruptors can cause the following, among others: reproductive anomalies (morphological and functional gonadal dysfunction, e.g., infertility and decreased libido) and congenital malformations (altered embryonic and fetal intrauterine development) 2,6,7,8.

The principal effects of exposure to endocrine disruptors on male fertility are temporal reduction in sperm concentration and quality 9 , high incidence of cryptorchidism and hypospadias 10 , and altered sex ratio 11,12 .

Despite the diversity of habits and cultures around the world, an increase in male infertility has been observed, apparently constituting an international phenomenon 13,14,15,16,17, although alterations in fertility can be said to suffer influences from physical, chemical, and/or psychological factors.

Male reproduction involves complex and delicate processes and depends on normal development and organization during the fetal period as well as during growth and puberty 18 . In- 
terference in sex hormone function during these phases can thus have repercussions throughout adult life.

It is undeniable that good quality semen is essential for reproductive success. This quality appears to have been directly affected in recent years, and evidently there are now unfavorable trends in male reproductive health 19.

For example, Carlsen 20 demonstrated a $45 \%$ drop in human sperm count, from an average of 113 million per ml of semen in 1940 to 66 million in 1990, potentially jeopardizing male fertility 7,21 .

Since the 1970 s various authors have reaffirmed the possible significant drop in sperm quality and consequently an increase in male infertility rates 13,22 . The actual causes of increased infertility remain controversial 13,14,16,23, but research suggests that many substances to which men are exposed and than can affect their fertility may be work-related 24,25,26.

The international technological shift in industrial and agricultural development in the $20^{\text {th }}$ century involved handling and exposure to various substances that are harmful to humans, some of which affecting the male reproductive system, such as pesticides, metals, estrogen-like substances, chlorinated compounds, etc. 3,13,16,27.

This raises the hypothesis that the effects of these substances on the male reproductive organs may shed light on numerous issues related to the increase in male infertility.

Some $6 \%$ of reproductive-age men present male infertility. The most frequent causes, accounting for $90 \%$ of the total, are associated with spermatogenesis. The other causes are related to alterations in sperm transport and accessory glands in the male genital tract $(6 \%)$, erectile disorders $(2 \%)$, ejaculatory disorders (1\%), and functional alterations in the sperm and coitus (1\%) 28 . There may be absence of sperm (azoospermia), a decrease in the number (oligozoospermia), alteration in form (teratozoospermia), in the motile capacity (astenozoospermia), or in the vitality (necrospermia) 29,30.

Exposure to endocrine disruptors can modify hormone metabolism by altering the synthesis and/or breakdown of testosterone, FSH, LH, or other hormones. Most steroid metabolism occurs in the liver, the main target for some exogenous toxic substances 31 .

\section{Methods}

The current study reviewed the specialized literature for substances that can act as endocrine disruptors and lead to male infertility through occupational exposure.
The research consisted of a bibliographic survey and data collection in books and articles in journals or periodicals. The material collected for the study was limited to that published in the Portuguese, English, and Spanish languages, based on the review of the domestic and international literature through books, articles in indexed periodicals and websites. Due to the scarcity of material published in this area, we did not adopt any restriction on the time period researched.

The descriptors researched in English were the following, in addition to their Portuguese and Spanish equivalents: infertility, male infertility, azoospermia, endocrine disruptors, environmental contaminants, infertility versus occupational, effects of occupational exposure, male reproductive system, gonads, reproduction and human development, male gonadal hormone control, chronic effects of pesticides, heavy metals, and others, toxicology, male infertility, and occupational exposure to endocrine disruptors.

\section{Male infertility and occupational exposure to endocrine disruptors}

External causes include factors that are exogenous to the body, and exposure to them can occur consciously, for example in alcohol consumption or smoking, or unconsciously or accidentally as with infections or occupational or environmental contamination 28 .

The numerous external causes of infertility include exposure to work-related substances; contact with toxic substances like pesticides, or exposure to extremely hot areas such as blast furnace operations 3,13,30,31,32.

Chia \& Tay 33 assessed a total of 640 men who were incapable of conceiving with their wives, asking about the men's exposure to agents known to affect spermatogenesis, such as alcohol consumption, smoking, and stress. They evaluated total semen concentration, density, motility, viability, and morphology. Smoking proved to be a significant risk factor and exposure to electromagnetic fields and high stress levels may have contributed to this increased risk of infertility in occupations with these characteristics, although the factors require further in-depth study and validation of the hypothesis.

There was a significant increase in the incidence of testicular cancer in the 20th century, which could be correlated with the increase in male infertility. There has also been an increase in the incidence of prostate cancer 34 . A signifi- 
cant difference is that testicular cancer occurs in young, reproductive-age men, while prostate cancer occurs mainly in elderly men, so that the latter increase is explained mainly by the increase in the population's mean age.

Several studies have correlated the increase in testicular cancer with exposure to certain substances 35 . As important as the chemical agent is the duration of exposure to the inductive agent 32 .

In recent decades, the increasing incidence of testicular cancer has been associated with exposure to endocrine disruptors like pesticides and industrial residues 36,37.

Sheiner et al. 38 investigated the influence of work conditions (such as exposure to toxic substances) on reproduction. The study concluded that industrial and construction workers present an increased infertility rate as compared to other professions, due mainly to greater exposure to stress. Workers in these sectors smoked more and were more exposed to noise and physical effort as compared to other professions. These workers presented sperm abnormalities, hormonal alterations, varicocele, and/or cryptorchidism.

Among the many external causes of infertility are exposure to substances related to occupation, such as pesticides, polychlorinated biphenyls (PCBs), dioxins and furans, ethanol, phenols, phthalates, and metals like cadmium, lead, mercury etc. 7,10,36 and adverse work situations (exposure to hot areas like blast furnace operations etc.) $13,28,29,32$.

\section{Cadmium}

Some toxic substances act on the testes, causing problems in spermatogenesis and spermiogenesis. One example is cadmium 39.

Industrial cadmium exposure is extremely relevant, affecting more than 1,500,000 workers a year in the United States alone 40 . Cadmium is used in pesticides, batteries, rubber processing, production of pigments, and galvanizing 41 . It is also bioaccumulative and persistent in the environment (with a half-life of 10-30 years) 14 .

Cadmium can directly injure the testes. A testicular toxin and various derived compounds were shown to induce severe damage to the spermatogenic epithelium in an animal model 39. The effect of cadmium on the testes appears to be manifested mainly in the Sertoli cells, which present more morphological changes under scanning electron microscopy. Cadmium can also interfere with the normal functions of mitochondrial enzymes 28 .
Testicular lesion from cadmium is primarily vascular, and the vascular damage determines the degree of lesion in the germ cells and Leydig cells. This lesion can generate Leydig cell tumors, tubular degeneration (in highdose exposure), and atrophy 42 , in addition to inducing tissue necrosis and deficient androgen production 42,43 .

In chronic exposures to lower doses, the greater availability of metallothionein, bound to cadmium, means that the testicular lesion is less aggressive as compared to cases of acute intoxication 44 .

In a study by the World Health Organization (WHO) on the effects of lead and cadmium in the blood of adult men, the overall results indicate that even low-level exposure to lead $(400 \mu \mathrm{g} / \mathrm{l})$ and cadmium $(10 \mu \mathrm{g} / \mathrm{l})$ can significantly reduce the quality of semen, although the study did not show conclusive evidence of male endocrine reproductive alterations $45,46,47,48$.

\section{$\underline{\text { Lead }}$}

Reproductive dysfunction has been described in men exposed to lead at the workplace, including oligozoospermia and dose-dependent astenozoospermia $48,49,50$.

Blood and semen samples were analyzed from battery factory workers, showing an inverse association between plasma lead levels and sperm volume and concentration.

Significant correlations were observed between lead, dehydratase, and protoporphyrin levels and reproductive parameters, indicating a decrease in sperm density and motility and viability counts and an increase in abnormal sperm head morphology 45 .

Other authors have also reported a reduction in spermatogenesis among battery workers as one of the findings in symptomatic lead poisoning $51,52,53,54$.

The 1950s witnessed a reduction in gonadotropin secretion among individuals exposed to lead, while moderate exposure only led to higher FSH levels 55.

Studies on workers in lead foundry workers showed hypogonadism and decreased serum testosterone, with a reproductive and endocrine impact, especially in the hypothalamic-pituitary-testicular axis, associated with occupational exposure to inorganic lead 54,56.

Another lead foundry study evaluated exposure and damage over time. The study demonstrated a non-progressive increase in LH in individuals exposed for less than one year, while those exposed for more than three years showed a reduction in both testosterone and the testos- 
terone/steroid transport protein ratio, suggesting a correlation between testicular dysfunction and duration of exposure 58 .

Studies in rodents have also demonstrated both a direct effect of lead on the testes and interference in the hypothalamic-pituitary axis 59,60 .

Studies in laboratory animals exposed to lead showed lower plasma LH levels after stimulation with GnHR as compared to controls, in addition to decreased inhibin/FSH ratio 61 .

Continuous intrauterine exposure of male rodents also showed harmful effects on male sexual maturity and reduced neonatal sex steroid levels. In addition, exposure during puberty induced a reduction in testosterone concentrations and decreased plasma LH 62 in males exposed to high lead levels, thus suggesting secondary effects in relation to the hypothalamicpituitary effects, with alterations in FSH levels 63 .

Lead can reduce the amount of sulfated steroids excreted in the urine and can cause a reduction in testosterone levels and sperm concentration 64 . In addition to the effects on hormone levels, Assennato et al. 52 describe a reduction in sperm concentration by a direct, nonhormonal effect, in sperm production or transport. A direct effect of lead on the testes has also been shown in rodents 55,65

Animal studies appear to confirm lead's toxic effect on the reproductive system. Excess lead intake can result in decreased sperm production and testicular weight 59 .

Studies in monkeys chronically exposed to lead showed alterations in Sertoli cell function 53,66

Lead can alter prostate secretory function 46 (concentration of zinc, acid phosphatase, and citric acid in the seminal fluid). Donovan et al. 67 showed that in animals lead, like other divalent cations, can inhibit the binding of dihydrotestosterone to specific receptors in the prostate and seminal vesicle.

A study in which men were exposed to lead in the workplace showed that increased levels were associated with decreased libido and an increase in semen abnormalities 49 . The principal source of lead contamination occurs in workplaces 28 .

\section{Mercury}

Research on mercury increased after the accident in Japan in 1968, when more was learned about exposure to this metal in rats and humans 68 .

Mercury can concentrate in the kidneys, cerebellum, and testes. Mercury poisoning leads to neurological disorders, kidney failure, and infertility 68.

Mercury can interfere in spermatogenesis and also affects the epididymis. It can also cause Young syndrome, associated with obstructive lesion of the upper epididymis 69 .

\section{Copper}

Copper can act on FSH receptors, interfering in spermatogenesis 57 . In animals, the main endocrine alterations are in testosterone, LH 70, and FSH secretion 71 .

\section{Pesticides}

The main pesticides with effects described on the reproductive system are beta-HCH, carbaryl, chlordane, dicofol, dieldrin, DDT (dichlorodiphenyl-trichloro-ethane) and its metabolites, endosulfan, heptachloro and H-epoxide, lindane (gamma-HCH), malathion, mathomyl, methoxychlor, mirex, oxychlordane, parathion, synthetic pyrethroids, toxaphene, and transnonachlor 37 .

A recent study by Dalvie 72 attempted to elucidate the effects of the pesticide DDT on workers from the province of Limpopo in South Africa. The study hypothesis was that there could be long-term reproductive effects on malaria vector control workers who were regularly exposed to DDT. The study measured sperm count, density, and motility. Normal morphology recording included $2.5 \pm 1.8 \%$ of the individuals. Most $(84 \%)$ of the morphological counts were below the WHO and Tygerberg criteria, with the highest individual recording at $6 \%$, which is precisely on the subfertility line according to the Tygerberg criterion. Persistent problems with sexual function extended to 10$20 \%$ of the patients. The most prevalent genital abnormality $(71 \%)$ was abnormal testicular placement 72 .

According to several studies, DDT and some organic solvents lead to decreased fertility and altered sperm counts 42,73 .

DDT can also delay puberty $7,28,42,74,75$. The estrogenic activity of DDT isomers is very weak as compared to estradiol (103-106 less powerful), but the properties of bioaccumulation and long half-life indicate that human exposure levels can cause estrogenic effects under certain circumstances 7,76 and act as an androgenic agonist at high doses 77,78,79.

DDE, a metabolite of DDT, has anti-androgenic action and can also jeopardize estrogen metabolism in its synthesis or breakdown and physiological elimination 77,78 . According to Je- 
quier 28, DDE can suppress the spermatogenic epithelium in humans.

Exposure to the pesticide DBCP (1,2-dibromo-3-chloropropane) in rodents profoundly affected the germ cells and androgen-dependent sexual differentiation (there was a reduction in testicular mass, androgen levels, and size of the hypothalamus) 19,75.

DBCP can reduce sperm production. Exposure to this product can be associated with a reduction in the number of male births $3,7,76$. It can reduce the concentration of ejaculated sperm in exposed workers as compared to samples in unexposed men 80 . Removing workers from the exposure site allows a return to normal values, while those suffering azoospermia remain sterile. Testicular biopsies show that the target of DBCP is the spermatogonium 79 .

A study on farm workers who handled pesticides showed the action of the latter over a three-year period on testosterone metabolism. A significant increase was observed in FSH, PRL, and testosterone. An immediate effect was the temporary reduction of testosterone levels. There was also a reduction in estradiol levels. An important caveat is that the study involved a small number of workers 42 .

According to Gray 81, the pesticide linuron displays anti-androgenic activity. It increases the incidence of testicular tumors in rodents. It can lead to pituitary stimulation, with an increase in $\mathrm{LH} 42$.

The pesticide vinclozolin can have anti-androgenic effects. The metabolites of vinclozolin, M1 and M2, but not the substance itself, competitively inhibit the binding of androgens to the androgen receptor in mammals 82 . Exposure of adult and pubertal rats to the pesticide altered the hypothalamic-pituitary function 83 .

Exposed workers in factories producing lindane showed a significant increase in LH, a non-significant increase in FSH, and a slight decrease in testosterone 84.

Studies have shown that lindane can accumulate in the testes, damaging the germinal epithelium and the number of spermatids and Sertoli cells in humans 84 .

The pesticide procimidone binds to the androgen receptor, acting as an antagonist in monkey cells, and in the laboratory it is capable of inhibiting the transcription induced by dihydrotestosterone 81 . In rats it induced hypospadias and smaller accessory glands and reduced the size of various androgen-dependent tissues such as: prostate, seminal vesicle, and glans penis, even when these rodents were exposed to low doses 74 .

Endosulfan is a xenoestrogen that is capable of increasing prolactin expression and com- peting with estrogens for the estrogen nuclear receptor 84 . According to Saiyed et al. 31 , exposure to endosulfan in boys can delay sexual maturity and interfere with hormone synthesis.

\section{Dioxins}

Dioxins are the result of various industrial processes and are considered the most toxic anthropogenic agents. Studies with dioxin in sexually mature laboratory animals showed the effects of exposure to relatively high doses. The animals displayed decreased spermatogenesis, decreased testicular weight, and abnormal testes with reduced fertility 85 .

A study on sexually mature laboratory animals exposed to high doses of dioxins showed alteration of accessory sex organs 85 .

Dioxins can affect libido and fertility, causing changes in the sexual behavior of male fish, birds, mammals, and reptiles $83,86,87$. Tetrachloro-dibenzo-p-dioxin (TCDD) can interfere with libido 73.

A study showed similar effects in animals exposed to dioxin in uterus. This study reported that sperm counts have dropped and alterations in the male reproductive tract have increased since the 1950s 14,88.

TCDD can have an anti-androgenic and anti-estrogenic effect 89 , inducing a decrease in the testicular response to LH 89,90.

The effects of high exposure to TCDD and “TCDD-like" compounds on important sites for development and reproduction have been recognized for years 89 . The reproductive system has even been considered the most sensitive "end point" for dioxins 83,89 .

\section{PCBs}

According to Brouwer et al. ${ }^{85}$, PCBs can affect not only estrogen levels but also those of androgenic, thyroid, pituitary, corticosteroid, and other hormones.

Some of the analogs or metabolites of PCBs act as endocrine disruptors 85 . Both estrogenic and anti-estrogenic effects can be induced by these substances 91,92. The levels of some PCB analogs were inversely correlated to sperm motility in semen samples in which the sperm concentration was less than 20 million/ml 92 .

Boys born to women exposed to PCBs presented penile underdevelopment 42,90 . Other studies have described a powerful gonadotoxic action of PCBs, and exposure to these agents induced major testicular alterations 28 . 


\section{Ethylene dibromide (EDB)}

EDB, a substance used to remove lead traces from gasoline 93 , has testicular and post-testicular effects. A study of workers exposed to this substance indicated an increase in the number of abnormal sperm and decreased sperm concentration 94 . Even short exposure can reduce sperm velocity and semen volume 31,95.

\section{Phthalates}

Phthalates are substances used in the manufacturing of automobiles, medical supplies, plastics, beverage containers, coating of metal cans etc. ${ }^{42}$. One of the principal forms of exposure is through food, in addition to medical materials and by occupational contact $96 . \mathrm{Ph}$ thalates can alter reproductive development regardless of binding to androgen or estrogen receptors. Some phthalate esters inhibit steroidogenesis in Leydig cells, displaying an anti-androgenic effect 88 . Through exposure by food, they can cause testicular atrophy and reduced fertility 30,74 . In pubertal male rats, phthalates can alter testicular function, producing malformations in androgen-dependent tissues 74 .

Data have demonstrated that perinatal exposure to a variety of phthalate esters alters the development of the male reproductive tract in an anti-androgenic way, causing underdevelopment and agenesis of the epididymis at relatively low doses 81 .

\section{Others}

Polyvinyl chloride (PVC) in exposed workers is associated with cancer of the testes 42 .

In rats, ethanol can cause a decrease in plasma testosterone and LH levels 5 .

\section{Final remarks}

The themes approached in the field of workers' health are important for any country's economic system. The issue of male infertility caused by occupational exposure is pertinent worldwide. Protection of workers against exposure may also allow preventing other alterations and injuries to the human body.

In addition to the reproductive system, endocrine disruptors can interfere in other areas such as the immune and endocrine-metabolic systems and can even cause diseases like cancer. The effects of chronic exposure can interfere in growth, physiology, behavior, and reproduction. Monitoring chronic effects requires sufficient time for the manifestations to occur.

Progress is needed in the knowledge of possible effects of exposure on male fertility. Such progress will allow the development of preventive measure within the field of workers' health. Studies in this field should be encouraged, since they are scarce in light of the almost unlimited range of substances to which workers are potentially exposed.

\section{Resumo}

Um significativo aumento da incidência de infertilidade masculina tem sido descrito na literatura mundial, o que gera questionamentos sobre suas causas. Parte deste efeito pode dever-se à ação de substâncias tóxicas sintéticas sobre o sistema endócrino (endocrine disruptors ou interferentes endócrinos), sendo muitas delas utilizadas em processos laborais. Realizou-se revisão crítica da literatura especializada sobre fatores químicos de origem laboral capazes de provocar infertilidade masculina. Entre os principais endocrine disruptors que podem causar infertilidade masculina destacam-se agrotóxicos, como DDT, linuron e outros; metais pesados, como mercúrio, chumbo, cádmio e cobre; além de substâncias de utilidades variadas ou que correspondem a resíduos de processos industriais, como dioxinas, bifenilas policloradas, dibromoetileno, ftalatos, PVC e etanol. Disfunção gonadal e má formação congênita foram as principais alterações descritas como causadas por estas substâncias sobre o aparelho reprodutor masculino. Conclui-se que, apesar da escassez de estudos sobre o tema, a relevância do risco faz com que estes sejam estimulados, assim como que se tomem medidas preventivas para se evitar a exposição de trabalhadores a substâncias que carreiem tais riscos.

Infertilidade Masculina; Exposição Ocupacional; Sistema Endócrino 


\section{Contributors}

E. K. R. Queiroz and W. Waissmann participated equally in the design, elaboration, formatting, and revision of the article.

\section{References}

1. Brown AE. Pesticides and the endocrine system. College Park: Department of Entomology, University of Maryland; 1999. (Pesticide Information Leaflet Series, 34).

2. Waissmann W. Health surveillance and endocrine disruptors. Cad Saúde Pública 2002; 18:511-7.

3. Cox C. Masculinity at risk. Journal of Pesticide Reform 1996; 16:2-7.

4. Kavlock RJ, Daston GP, DeRosa C, Fenner-Crisp P, Gray LE, Kaattari S, et al. Research needs for the risk assessment of health and environmental effects of endocrine disruptors: a report of the U.S. EPA-sponsored workshop. Environ Health Perspect 1996; 104:715-40.

5. World Health Organization. World Water Day 2001: pollution from industry, mining and agriculture water, sanitation and health. Geneva: World Health Organization; 2001.

6. Lemos H. Poluentes orgânicos persistentes. A intoxicação química do planeta. Rio de Janeiro: Instituto Brasil PNUMA; 2001.

7. Santamarta J. Por um futuro sem contaminantes orgânicos persistentes. Agroecologia e Desenvolvimento Rural Sustentável 2001; 2:46-56.

8. Nelson P. Epidemiology, biology, and endocrine disrupters. Occup Environ Med 2003; 60:541-2.

9. Pflieger-Bruss S, Schuppe HC, Schill WB. The male reproductive system and its susceptibility to endocrine disrupting chemicals. Andrologia 2004; 36:337-45.

10. Melnick RL. Introduction - workshop on characterizing the effects of endocrine disruptors on human health at environmental exposure level. Environ Health Perspect 1999; 107 Suppl 4:603-4.

11. Mocarelli P, Brambilla PM, Gerthoux DG, Patterson N. Change in sex ratio with exposure to dioxin. Lancet 1996; 348:409.

12. Whitten PL. Effects of a phytoestrogen diet on estrogen-dependent reproductive processes in immature female rats. Advances of Modern Environmental Toxicology 1992; 21:311.

13. Pasqualotto FF, Locambo CV, Athayde KS, Arap S. Measuring male infertility: epidemiological aspects. Rev Hosp Clín Fac Med Univ São Paulo 2003; 58:173-8.

14. Swan HS, Elkin EP, Fenster L. Have sperm densities declined? A reanalysis of global trend data. Environ Health Perspect 1997; 105:1228-32.

15. Swan HS, Elkin EP, Fenster L. The question of declining sperm density revisited: an analysis of 101 studies published 1934-1996. Environ Health Perspect 2000; 108:961-6.
16. Golden AL, Moline JM, Bar-Chama N. Male reproduction and environmental and occupational exposures: a review of epidemiologic methods. Salud Pública Méx 1999; 41:93-105.

17. Auger J, Kunstmann JM, Czyglik E, Jouanet P. Decline in semen quality among fertile men in Paris during the past 20 years. N Engl J Med 995; 332:281-5.

18. Jensen TK, Vierula M, Hjollund NH, Saaranen M, Scheike T, Saarikoski S, et al. Semen quality among Danish and Finnish men attempting to conceive. The Danish First Pregnancy Planner Study Team. Eur J Endocrinol 2000; 142:47-52.

19. Guillette Jr. LJ, Crain DA. Environmental endocrine disrupters: an evolutionary perspective. New York: Taylor \& Francis; 2000.

20. Carlsen E, Giwercmen A, Keiding N, Skakkebaek N. Evidence for decreasing quality of semen during past 50 years. BMJ 1992; 305:609-13.

21. Skakkebaek NE, Raipert-De Meyts E, Main KM. Testicular dysgenesis syndrome: an increasingly common developmental disorder with environmental aspects. Hum Reprod 2001; 16:972-8.

22. Nelson C, Bunge R. Semen analysis: evidence for changing parameters of male fertility potential. Fertil Steril 1974; 25:503-7.

23. Multigner L, Oliva A. Secular variations in sperm quality: fact or science fiction? Cad Saúde Pública 2002; 18:403-12.

24. De Los Rios P, Manini N, Tosatti E. Dynamical Jahn-Teller effect and Berry phase in positively charged fullerenes: basic considerations. Phys Rev B Condens Matter 1996; 154:7157-67.

25. Lerda D, Rezzi R. Study of reproductive function in persons occupationally exposed to 2,4-dichlorophenoxyacetic acid (2,4-D). Mutat Res 1991; 262: 47-50.

26. Petrelli G, Musti M, Figa-Talamanca I. Exposure to pesticides in greenhouses and male fertility. $G$ Ital Med Lav Ergon 2000; 22:291-5.

27. Cooper RL, Kavlock RJ. Endocrine disruptors and reproductive development: a weight-of evidence overview. J Endocrinol 1997; 152:159-66.

28. Jequier AM. Male infertility - a guide for the clinician. Oxford: Blackwell Science; 2002.

29. Bigazzi PE. Immunology of the male reproductive system. New York: Marcel Dekker; 1987.

30. Kazantzis G, Lam TH, Sullivan KR. The mortality of cadmium-exposed workers: a five-year update. Scand J Work Environ Health 1988; 14:220-3.

31. Saiyed H, Dewan A, Bhatnagar V, Shenoy U, Shenoy $\mathrm{R}$, Rajmohan H, et al. Effect of endosulfan on 
male reproductive development. Environ Health Perspect 2003; 111:1958-62.

32. Joffe M. Are problems with male reproductive health caused by endocrine disruption? Occup Environ Med 2001; 58:281.

33. Chia SE, Tay SK. Occupational risk for male infertility: a case-control study of 218 infertile and 227 fertile men. J Occup Environ Med 2001; 43:946-51.

34. Waalkes MP, Rehm S, Sass B, Kovatc R, Ward JM. Chronic carcinogenesis and toxic effects of a single subcutaneous dose of cadmium in male NFS and C57 mice and male Syrian hamsters. Toxic Subst J 1994; 13:15-28.

35. Swan SH, vom Saal S. Alterations in male reproductive development: the role of endocrine disrupting chemicals. In: Metzler $\mathrm{M}$, editor. The handbook of environmental chemistry. v. 3M: endocrine disruptors. Berlin: Springer-Verlag; 2002. p. 131-70.

36. Eertmans F, Dhooge WM, Stuyvaert S, Comhaire F. Endocrine disruptors: effects on male fertility and screening tools for their assessment. Toxicol In Vitro 2003; 17:515-24.

37. Carman NJ. Endocrine-disrupting chemicals. http //www.ghasp.org/publications/toxics_report/edc. htm (accessed in Feb/2005).

38. Sheiner E, Hadar A, Shoham-Vardi I, Hallak M, Katz M, Mazor M. The effect of meconium on perinatal outcome: a prospective analysis. J Matern Fetal Neonatal Med 2002; 11:54-9.

39. Boscolo P, Sacchettoni-Logroscino G, Ranelletti FO, Gioia A, Carmignani M. Effects of long-term cadmium exposure on the testis of rabbits: ultrastructural study. Toxicol Lett 1985; 24:145-9.

40. Ragan HA, Mast TJ. Cadmium inhalation and male reproductive toxicity. Rev Environ Contam Toxicol 1990; 114:1-22.

41 Kidambi SS, Lee DK, Ramamoorthy A. Interaction of $\mathrm{Cd}$ and $\mathrm{Zn}$ with biologically important ligands characterized using solid-state NMR and ab initio calculations. Inorg Chem 2003; 42:3142-51.

42. Waissmann W. Endocrinopatologia associada ao trabalho. In: Mendes R, organizador. Patologia do trabalho. São Paulo: Editora Atheneu; 2003. p. 1093-138.

43. Waalkes MP, Anver M, Diwan BA. Carcinogenic effects of cadmium in the noble (NBL/Cr) rat: induction of pituitary, testicular, and injection site tumors and intraepithelial proliferative lesions of the dorsolateral prostate. Toxicol Sci 1999; 52:15461.

44. Favino A. Studio della funzione andrógena di uomini esposti al cadmio. Med Lav 1968; 59:105-9.

45. Telisman S, Cvitkovic P, Jurasovic J, Pizent A, Gavella M, Rocic B. Semen quality and reproductive endocrine function in relation to biomarkers of lead, cadmium, zinc, and copper in men. Environ Health Perspect 2000; 108:45-53.

46. Alloway BJ. Heavy metals in soils. New York: John Wiley Inc.; 1990.

47. U.S. Public Health Services. Toxicological profile for cadmium on CD-ROM. Atlanta: Agency for Toxic Substances and Disease Registry/U.S. Public Health Services; 1997.

48. Hamilton A, Hardy IL. Industrial toxicology. 2nd Ed. New York: Paul B. Hoeber; 1949.
49. Lancranjam I. Reproductive ability of workmen occupationally exposed to lead. Arch Environ Health 1975; 30:396-401.

50. Rom WN. Effects of lead on the female and reproduction: a review. Mt Sinai J Med 1976; 43:542-52.

51. Rachootin P, Olsen J. The risk of infertility and delayed conception associated with exposures in the Danish workplace. J Occup Med 1983; 25:394-402.

52. Assennato G, Paci C, Baser ME, Molinini R, Candela RG, Altamura BM, Giorgino R. Sperm count suppression without endocrine dysfunction in lead-exposed men. Arch Environ Health 1987; 42:124-7.

53. McGregor AJ, Mason HJ. Chronic occupational lead exposure and testicular endocrine function. Human Exp Toxicol 1990; 9:371-6.

54. Cullen MR, Kayne RD, Robins JM. Endocrine and reproductive dysfunction in men associated with occupational inorganic lead intoxication. Arch Environ Health 1984; 39:431-40.

55. Raule A, Morra G. Prime ricerche sulla funzionalita gonadotropica preipofisaria negli intossicati da piombo. Med Lav 1952; 43:262-5.

56. Cullen MR, Robins JM, Eskenazi B. Adult organic lead intoxication: presentation of 31 new cases and review of the recent advances in literature. Medicine 1983; 62:221-47.

57. Weibe JP, Salhanick AI, Myers KI. On the mechanism of action of lead in the testis: in vitro suppression of FSH receptors, cyclic AMP and steroidogenesis. Life Sci 1983; 32:1997-2005.

58. Rodamilans M, Osaba MJ, To-Figueras J, Rivera Fillat F, Marques JM, Perez P, et al. Lead toxicity on endocrine testicular function in an occupationally exposed population. Hum Toxicol 1988; 7:125-8.

59. Saxena DK. Lead induced testicular changes in protein malnourished rats. Folia Histochem $\mathrm{Cy}$ tobiol 1989; 1:57-62.

60. Eyden BP, Maisin JR, Mattelin G. Long-term effects of dietary lead acetate on survival, body weight and seminal cytology in mice. Bull Environ Contam Toxicol 1978; 19:266-72.

61. Foster WG. Reproductive endocrine effects of chronic lead exposure in the male cynomolgus monkey. Reprod Toxicol 1993; 7:203-9.

62. Camoratto AM. Inhibition of rat pituitary growth hormone release by subclinical levels of lead. Toxicologist 1990; 10:641.

63. Petrusk P. Lead poisoning and reproduction: effects on pituitary and serum gonadotropins in neonatal rats. Environ Res 1979; 19:383-91.

64. Apostoli PL. Romeo E, Peroni A, Ferioli S. Ferrari F, Pasini FA. Steroid hormone sulphation in lead workers. Br J Ind Med 1989; 46:204-8.

65. Murthy RC. Lead induced ultrastructural changes in the testis of rats. Exp Pathol 1991; 42:95-100.

66. Gustafson A. Occupational lead exposure and pituitary function. Int Arch Occup Environ Health 1989; 61:277-81.

67. Donovan MP, Schein LG, Thomas JA. Inhibition of androgen-receptor interaction in mouse prostate gland cytosol by divalent metal ions. Mol Pharmacol 1980; 17:156-62.

68. Eto K, Yasutake A, Miyamoto K, Tokunaga H, Otsuka Y. Chronic effects of methylmercury in rats. 
II. Pathological aspects. Tohoku J Exp Med 1997; 182:197-205.

69. Hendry WF, A'Hern RP, Cole PJ. Was young's syndrome caused by exposure to mercury in childhood? BMJ 1993; 307:1579-82.

70. Thoreux-Manley A, Velez de la Calle JF, Olivier MF, Soufir JC, Masse R, Pinon-Lataillade G. Impairment of testicular endocrine function after lead intoxication in the adult rat. Toxicology 1995; 100:101-9.

71. Sokol RZ, Madding CE, Swerdloff RS. Lead toxicity and the hypothalamic-pituitary-testicular axis. Biol Reprod 1985; 33:722-8.

72. Dalvie MA, Myers JE, Thompson ML, Robins TG, Omar S, Riebow J. Exploration of different methods for measuring DDT exposure among malaria vector-control workers in Limpopo Province, South Africa. Environ Res 2004; 96:20-7.

73. Hakin LS, Oates RD. Non-surgical treatment of male infertility: specific therapy. In: Lipshultz LI, Howards SS, editors. Infertility in the male. St. Louis: Mosby Year Book; 1997. p. 395-402.

74. Metzler M, editor. The handbook of environmental chemistry. Berlin: Springer-Verlag; 2002.

75. Moreira JC, Wolff M. Dietary and reproductive determinants of plasma organochlorine levels in pregnant women in Rio de Janeiro. Environ Res 2003; 91:143-50.

76. Gray Jr. LE, Kelce WR. Latent effects of pesticides and toxic substances on sexual differentiation of rodents. Toxicol Ind Health 1996; 12:515-31.

77. Toppari J. Male reproductive health and environmental xenoestrogens. Environ Health Perspect 1996; 104:741-803.

78. Kelce WR. The persistent DDT metabolite p,p'DDE is a potent androgen receptor antagonist. Nature 1995; 375:581-5.

79. Potashnik G, Abeliovich D. Chromosomal analysis and health status of children conceived to men during or following dibromochloropropaneinduced spermatogenic suppression. Andrologia 1985; 17:291-6.

80. Whorton DRM, Krauss SM, Milby TH. Infertility in male pesticide workers. Lancet 1977; 2:1259-60.

81. Gray JR. Prostate cancer risk groups and comparisons: fruitless or fruitful? J Clin Oncol 2002; 20:4129-30.

82. Holden H. Further mortality studies on works exposed to cadmium fumes. In: Seminar on Occupational Exposure to Cadmium. London: Cadmium Association; 1980. p. 23-4.

83. Assunção JV, Pesquero CR. Dioxinas e furanos: origens e riscos. Rev Saúde Pública 1999; 33:52330.
84. Tomezak S, Baumann K, Lehnert G. Occupational exposure to hexachlorocyclohexane. Int Arch Occup Environ Health 1981; 48:283-7.

85. Brouwer A, Longnecker MP, Birnbaum LS, Cogliano J, Kostyniak P, Moore J, et al. Characterization of potential endocrine-related health effects at low-dose levels of exposure to PCBs. Environ Health Perspect 1999; 107:639-49.

86. Ribeiro G. Os pesticidas como disruptores endócrinos nos peixes. http://www.fmv.utl.pt/stf/ sem0001/G04.htm (acessed on Feb/2003).

87. Giwercman A, Carlsen E, Keiding N, Skakkebaek NE. Evidence for increasing incidence of abnormalities of the human testis: a review. Environ Health Perspect 1993; 101:65-71.

88. Mantovani A. Problems in testing and risk assessment of endocrine disrupting chemicals with regard to developmental toxicology. Chemosphere 1999; 39:1293-300.

89. Eskenazi B, Kimmel G. Workshop on perinatal exposure to dioxin-like compounds. II. Reproductive effects. Environ Health Perspect 1995; 103:143-5.

90. Bush B, Lambert G, Tarbell A. Polychlorinated biphenyl (PCB) and dichlorodiphenyl dichloroethylene (DDE) exposure among Native American men from contaminated Great Lakes fish and wildlife. Toxicol Ind Health 1996; 12:361-8.

91. Goldstein EG. Procedimentos para utilização de testes de toxicidade no controle de efluentes líquidos. São Paulo: Companhia de Tecnologia de Saneamento Ambiental; 1990.

92. Li LA, Wang PW, Chang LW. Polychlorinated biphenyl 126 stimulates basal and inducible aldosterone biosynthesis of human adrenocortical H295R cells. Toxicol Appl Pharmacol 2004; 195:92102.

93. Alexeeff GV, Kilgore WW, Li MY. Ethylene dibromide: toxicology and risk assessment. Rev Environ Contam Toxicol 1990; 112:49-122.

94. Ratcliffe JM, Schrader SMK, Steenland DE, Clapp $\mathrm{T}$, Turner RW. Semen quality in papaya workers with long term exposure to ethylene dibromide. Br J Ind Med 1987; 44:317-26.

95. Schrader SM, Turner TW, Ratcliffe JM. The effects of ethylene dibromide on semen quality: a comparison of short term and chronic exposure. Reprod Toxicol 1988; 2:191-8.

96. Wams TJ. Diethylhexylphthalate as an environmental contaminant: a review. Sci Total Environ 1987; 66:1-16.

Submitted on 12/May/2005

Final version resubmitted on 19/Aug/2005

Approved on 02/Sep/2005 